\title{
Institutional Activism, Auditor's Choice and Earning Management after the Enron Collapse: Evidence from France
}

\author{
Jamel Azibi $^{1}$, Hamza Azibi ${ }^{2}$, Hubert Tondeur ${ }^{3}$ \\ ${ }^{1}$ Faculty of Law, Economics and Management of Jendouba, Jendouba University, Tunisia and Arab East College \\ for Graduate Studies, KSA \\ ${ }^{2}$ Faculty of Law, Economics and Management of Jendouba, Jendouba University, Tunisia \\ ${ }^{3}$ Intec-Paris, Cnam University, France \\ Correspondence: Jamel Azibi, Arab East Colleges, P.O.Box 53354, Riyadh, KSA. E-mail: jamel.az1@gmail.com
}

Received: November 28, 2016

Accepted: January 18, $2017 \quad$ Online Published: January 21, 2017

doi:10.5539/ibr.v10n2p154

URL: http://dx.doi.org/10.5539/ibr.v10n2p154

\begin{abstract}
This paper treats the relation between institutional shareholders, auditor's choice and earning management after the Enron collapse in French context. This context is characterized by the weak of investor protection compared to Common Law countries and the presence of the higher ownership concentration. Three hypotheses are tested around this question. The Empirical results demonstrate that institutional investor has more incentives to control the manager opportunism through the discretionary accruals and influence negatively the appointment of the Big 4 auditors after Enron collapse.
\end{abstract}

Keywords: institutional shareholders, auditor's choice, audit quality, earning management and Enron collapse

\section{Introduction}

According to DeAngelo (1981), audit quality is the probability that the auditor will both detect and report a breach in the contract to provide fair accounting information. The contemporary researchers confirm that large audit firms provide a higher audit quality compared to the others audit firms (Becker et al. 1998).

The discovery of the financial statement scandal and the determinant role of the Big 4 auditors were characteristics of the end of 2001 and the starting of 2002. Enron-Andersen was the matter example in the World.

The consequence of this failure was very significant in particular on the Financials market. Cahan and Zhang (2006) found that share prices of Arthur Andersen clients reacted negatively between December $12^{\text {th }}, 2001$ and February $4^{\text {th }}, 2002$. This results signals that the reputation of large audit firms was damaged. This is new evidence and influences the audit market concentration after Enron failure (Asthana et al. 2003). This new feature of the audit market is a new opportunity for Non-Big 4 to justify their conservatism through their services.

To restore the confidence of the investor on the financial market, the United States Congress adopted the Sarbanes-Oxley Act in 2002. This security act creates the Public Company Accounting Oversight Board (PCAOB). This new authority is responsible for supervising the audit firms. In French context, the legislator established a financial security act (LSF) on in 2003. This new act creates "Hautes Commissariat aux Comptes: $\boldsymbol{H 3}$ '". This new authority is the equivalent to the PCAOB in the U.S context.

The interest of this paper is to analyse the perception of institutional shareholders and their active role in the firm corporate governance. To study this question, we use the perception of the institutional investor through the appointment of the legal auditor and the control and the manager opportunism.

Empirical results show that institutional ownership is negatively and significant associated to Big 4 appointment after Enron failure. This result demonstrates that the perception of the institutional investors has changed to Big Four audit services. This informs the radical change in the couple Audit Quality-Big Four. Furthermore, we find that institutional investor ownership is negatively and insignificantly associated to discretionary accruals after Enron collapse. This means that institutional investor exercises an insignificant control on earning management. 
This is due to the effectiveness of others corporate governance mechanisms in French context.

The remainder of this paper is organised as follows. Section 2 describes the the reforms of audit profession in the French context after the Security Law of 2003. Section 3 develops hypotheses related to the auditors' choice and institutional ownership after the Enron failure. Section 4 presents the audit quality differences through the discretionary accruals between Big 4 and Non-Big 4 after Enron collapse. Section 5 presents the sample and methodology, and section 6 demonstrates the empirical results. The last section summarizes the empirical findings and conclusion.

\section{The Reforms of the Audit Profession in France after the Law Security Act of 2003}

After the disclosure of the Enron failure, two major reactions recorded. The first related to the market reaction. The first study on this subject realized Chaney and Philipich (2002). They investigated the effect of the Enron audit failure on the reputation of Arthur Andersen clients only through the negative effects on stock prices. They find that Andersen's clients suffered from a significant negative reaction during key disclosure about Enron and Andersen. In the same perspective, Callen and Morel (2002) compared the daily stock returns of Andersen's clients with a control sample of other Big 5 auditors' clients over the period from October 2001 to January 2002. They showed that in the month when the failure of Enron was announced, Andersen brand name was negatively affected. In the same way, Krishnamurthy and al,. (2002) find that the market reaction reacted more negatively than when the news about Andersen was announced. They also noted that the market reacted more negatively to Andersen client than other Big 4 auditor clients. Cahan and Zhang (2006) studied the reaction of prices of actions of Andersen customers outside the United States (521 clients in 38 different countries). They find that the share prices of Andersen's clients reacted negatively between December $12^{\text {th }}, 2001$ and February $4^{\text {th }}, 2002$. Nelson et al. (2008) find that the stock of Andersen clients reacted more negatively relative to Big 4 clients. Those negative reactions demonstrate that Big 4 lost their brand name and reputation after Enron collapse. To resume, the results of those last studies attest the presence of the negative effect of the Enron-Andersen failure on the financial market. This is due to a lack of user confidence in the financial statement certified by the Big 4 auditor.

The second reaction is related to the development of the new legal rules on corporate governance. In $30^{\text {th }}$ July 2002, the United Stated Congress adopted the Sarbanes-Oxley Act (Public Law 107-204-July 30, 2002- 116 STAT.745). This new reform establishes new procedures of control to enforce audit, attestation, quality control and ethics standards. This mission is confided to the Public Company Accounting Oversight Board (PCAOB). This new independent authority possesses the right to impose the disciplinary measures if the audit firms do not respect the standards. The main goal of this appealing reform since 1934 is to establish the confidence on the financial market and protect the investors after the disclosure of the scandals series at the end of 2002.

In French context, a similar financial law was adopted in France in august 2003. This security act focuses on the financial transparency and improves the corporate governance mechanisms. This new reform in France establishes the H3C (Hautes Commissariat aux Comptes). This new authority is the equivalent of the PCAOB in United States. His role is to assure auditor independence and guarantee the respect of the ethics standards through permanent inspections and disciplinary measures (Azibi and al.2016).

From the same perspectives of the legislative reform, the European Parliament established new procedures of control through the European Directive. This reform of the audit profession insists on the importance of the ethical and the auditor independence (Directive of European Parliament, 2006).

\section{The Relation between Institutional Ownership and Big 4 Appointment after the Enron Collapse}

The certification of the financial statement by independent and competent auditor reduce reduces the likelihood of information asymmetries between users of this information. Palmrose (1988) find that audit report is a key factor of market reaction. This reaction depends on the auditor reputation. The practice shows the presence of the difference in audit services between big and small audit firms. This is due to the audit quality. DeAngelo (1981) defines this notion as the probability that the auditor will both detect and report a breach in the contract to provide fair accounting information. The independence and competence are two main characteristics of audit quality. Thee majority of last studies confirms that audit quality services are related to the Big 4 auditor. Simunic and Stein (1987) and Francis and Wilson (1988) suggested that large audit firm had established a brand name and they have incentives to protect their reputation on the audit market. Becker et al.(1998) confirmed this resultants. They demonstrated that Big 4 clients had less earning management compared to the Non-Big 4 clients in the United Stated context. Similarly, Françis et al. (1999) find that Big 4 auditors constraining aggressive and potentially opportunistic reporting of accruals for large enterprises listed on the NASDAQ over the period 1975-1994. This is mainly due to their human and financial resources. 
A priori, the archival audit studies focused on the determinants of auditor choice in various contexts. Ownership structure is one of these variables. DeFond, (1992), Francis and Wilson (1988) Watts and Zimmerman (1986) demonstrate that the ownership structure influences the choice of the large audit firm. Guedhami and Pittman (2006) find that large auditor don't reduce ownership concentration in international analyses over 31 countries. Wang, et al. (2008) studied the choice of auditors in China. Empirical results showed that State Owned Enterprises and non State Owned Enterprises appoint small auditors. In the same context, Jun Lin and Liu (2009) treat the choice of auditor during a period of 2001- 2004. They find that chinos firms with large controlling shareholders are less to hire Top 10 auditors. Ashbaugh and Warfield (2003) studied audit demand in Germany. They find a positive relationship between ownership dispersion and audit quality. Finally, Lenox (2005) investigated the relation between audit quality and management ownership in the United Kingdom. He fined a negative correlation between shares held by managers and audit quality.

The development of the institutional investor and their role in this last decade is very significant. This group of shareholders is characterized by their ability to carry out financial analysis of their needs information quality. Since the end of 1990, institutional investors have adopted active monitoring hypotheses in management (Gillan and Starks, 2000). Otherwise, the presence of institutional investor became one of the important characteristics of the financial market. The institutional investors use their ownership to pressure manager to act in the best of the shareholders. Maug (1998) notes that the decision of institutional investor is partially a function of share held by this group of investor. McConnell and Servaes (1990) find that the ownership of institutional investor is positively associated to the firm performance measured by the Tobin's Q. Generally, major of last researches confirm this relation.

Contrary to this deduction, Chen et al. (2006) suggests that institutional investors (pension funds, insurance companies, mutual funds) provide little monitoring in China context. It is clear that the role of institutional investor varied through countries, but their presence in the ownership structure influences the way in which management is monitored.

To resolve agency problem, Carcello et al. (2002) and Abott et al. (2003) suggest that audit quality presented by big audit firm mitigate agency cost and the likelihood of irregular and fraudulent financial statement. Otherwise, institutional investors choose the Big 4 to reduce agency problems. This monitor increases when the environment is characterized by the less legal protection. According to LaPorta et al. (1998), France suffers from a lack of investor protection. For this reason, institutional investors are active monitor (Wall Street Journal, 1995, 1996, 1997) in French context. This role became important after the Enron failure. This situation can influence the perception of the institutional investor on Big 4 services. Our first hypothesis is presented as follows:

Hypothesis 1: The perception of institutional investor changed to Big 4 after Arthur Andersen LLP role in Enron collapse.

\section{The Institutional Monitoring Activity after the Enron Collapse}

The majority of previous researches demonstrated that Big 4 audit firms have a high level of audit skills. DeFond and Jiambalvo (1993) demonstrated that audit and accounting practices affect the relationship between enterprises and theirs auditors and increase conflicts of interest. They showed that Big 4 resists to managers pressures and maintain their independent opinions. Becker et al. (1998) treated the audit quality differences through the discretionary accruals between Big 4 clients and Non-Big 4 clients in the United States context in 1993. They concluded that the corporation audited by Big 4 had less earning management compared to the corporation audited by small audit firm. Related to the last empirical findings, Françis et al. (1999) found that Big 4 auditors constraining aggressive and potentially opportunistic reporting of accruals for large enterprises listed on the NASDAQ between 1975 and 1994. Butler et al. (2004) investigated the relation between audit opinion modifications and discretionary accruals. They use Jones Model (1991) cross-section. The results indicated that there is a positive relation between modification of auditor opinions and the abnormal accruals. In sum, Big 4 have a greater ability to detect the accounting problems and the financial statements certified by this group of auditors had less earning management (Jeong and Rho, 2004).

The failure of Enron Co. at the end of 2001 demonstrated that one of large audit firms is not independent in their opinions. Arthur Andersen LLP expressed unqualified opinions on Enron financial statements. This situation increases the incentives of the institutional investor to appreciate their monitoring activity and influence the management choice. According to the McConnel and Servaes (1990), they find a significant positive relation between the share detained by the institutional investor and the financial performance of the corporation. Simith (1996), Gadhoum (2000) report a positive relation between corporate performance and institutional shareholdings. The explanation of this last empirical finding was advanced by Monks and Minow (1995). They 
suggest that institutional investors have the ability to monitor the manager decision. In the same way, Shleifer and Vishny (1997) used a comparative analysis across countries and they find that institutional share-holders influence corporate managers' decisions. It's important to note that the manager decision depends on the accounting choices and methods. For this reason, audit firms control the accounting methods used by the managers after the Enron failure. Specifically, Big 4 audit firms did not accord a flexibility choice of accounting methods to the managers (Francis et al, 1999) after the Enron Scandal, and the institutional investor increase their control to the management firm. Our second and third hypotheses are presented as follows:

H2: After the Enron scandal, Non-Big 4 clients report the same level of the discretionary accruals as the Big 4 clients in French context.

H3: Institutional investors have more incentives to control the manager opportunism through the discretionary accruals after Enron collapse.

\section{Methodology}

\subsection{Sample Selection}

The sample selected is composed of 140 French enterprises listed on SBF 250. Four criteria used for the selection sample in this study. First, every identified corporation must have all interest variables in Thomson Financial data bases over 2000-2007. Second, every corporation must have its annual reports available to identify the institutional investor's ownerships and their nationality. Third, banks, insurance companies and financial enterprises are excluded due to their accounting specificities and financial legislation. 141 French corporations examined over a period of six years, from 2000 to 2007 (1128 observations enterprise-year). The major percentage of our simple is operating in the services and electronics. This means that these corporations invest a higher amount in intangible assets and adopt Resource Based View theory in their organisation.

Table 1. Sample characteristic

\begin{tabular}{lcc}
\hline Sector & Worldscope Code & $\mathrm{N}$ \\
\hline Automotive & 1900 & 6 \\
Construction & 2800 & 6 \\
Chemicals , Drugs, Cosmetics and Health Care & $3400-2500$ & 8 \\
Electrical & 3720 & 8 \\
Electronics & 4000 & 18 \\
Food & $4600-2200$ & 6 \\
Metal, Oil and Gas & $5500-5800$ & 9 \\
Recreation & 6700 & 7 \\
Retailers & 7000 & 8 \\
Service & $8580-8510$ & 31 \\
Wholesalers & 8591 & 14 \\
Others & 3100 & 19 \\
Total & & 140 \\
\hline
\end{tabular}

\subsection{Variables Definition}

We use two different models in this study. The first one related to the auditor choice after Enron scandal. The dependent variable in this model is variable dummy, 1 if auditor is one of the Big 4 audit firms, 0 otherwise. We note that French law obliges enterprises to appoint two auditors. The assistant auditor does have a great effect on audit legal mission (Piot, 2003). In order to test our first hypothesis, we use the detention of major institutional investor to detect the perception of this group of investors to large audit firm after Enron collapse. According to following prior research, we use a Probit model in our first regression. Our model is as follows:

$$
\begin{array}{ll}
\text { If } 0<\text { Big } 4 \leq 2 ; & \text { Big } 4=1 \\
\text { If Big } 4<1, & \text { Big } 4=0
\end{array}
$$

$$
\begin{aligned}
& \text { Big } 4=\alpha_{0}+\beta_{1} I N S T+\beta_{2} L T D+\beta_{3} A S T R+\beta_{4} A G E+\beta_{5} S I Z E+\beta_{6} S I Z E^{2}+\beta_{7} O R G+\beta_{8} G R W+\beta_{9} T \\
& R I S K++\beta_{10} O R I S K+\beta_{11} M O M+\beta_{12} R O A+\zeta
\end{aligned}
$$

\section{Dependent variable}

Big 4: Dummy variable, which equal 1 if one of the two legal auditors is one of the Big 4 network, 0 otherwise; 


\section{Independent variables}

INST: Major institutional ownership percentage;

\section{Control variables}

LTD: Long term debt to total assets;

ASTR: Gross, property, plant and equipment to total assets;

AGE: Corporation age since the date of foundation

SIZE: Natural logarithm of total assets;

SIZE $^{2}$ : Size square;

ORG: Square root of total employer number.

GRW: (Total sales of next year divided by the total sales of current years) -1;

T Risk: Total risk (see Appendix 1);

O Risk: Operating risk (see Appendix 1);

MOM: Dummy variable, which equals 1 if the firm is listed on more than one market, 0 otherwise;

ROA: Return on assets;

$\zeta:$ Errors terms.

In order to examine the audit quality differences between large and small audit firms and the impact of institutional investors monitoring on opportunism of the manager, we use a discretionary accruals developed in the accounting literature. Previous studies used OLS Jones model (1991). Dechow et al. (1995) modify Jones model version appeared in 1991 and they added change in accountant's receivable as an addition independent variables that can express better the estimation of discretionary accruals. In 1996, Subramanyan found that modified Jones model cross-sectional is generally better than time-series model. In 2005, Kothari et al (2005) added return on assets that additional explanatory variable of discretionary accruals. They justified that discretionary accruals depends on corporation performance. In sum, we use the discretionary accruals model developed by Kothari et al. (2005). Discretionary accruals are estimated from the following equation:

$$
T A / A_{i j t-1}=\alpha_{0}\left(1 / A_{i j t-1}\right)+\beta_{1}\left(\Delta R E V_{i t}-\Delta R E C_{i t}\right) / A_{i j t-1}+\beta_{2} P P E_{i t} / A_{i j t-1}+\beta_{3} R O A_{t-1}+\xi_{t}
$$

Where

TA: total accruals $=$ Difference between earning and Operating cash flow

$\triangle \mathbf{R E V}$ : change in net revenues for firm $\mathrm{i}$ in industry $\mathrm{j}$ for year $\mathrm{t}$;

$\triangle$ REC: change in accounts receivable for firm $i$ in industry $j$ for year $t$;

PPE: gross property plant and equipment for sample firm $\mathrm{i}$ in industry $\mathrm{j}$ for year $\mathrm{t}$.

ROA: Return on Assets;

$\xi_{\mathrm{t}}$ : random error term.

According to Subramanyam (1996), DeFond and Park (1997), discretionary accruals are defined as the error terms from the following equation:

$$
e=T A / A_{i j t-1}-\left(\alpha_{0}\left[1 / A_{i j t-1}\right]+\beta_{1}\left[\left(\Delta R E V_{i t}-\Delta R E C_{i t}\right) / A_{i j t-1}\right]+\beta_{2}\left[P P E_{i t} / A_{i j t-1}\right]+\beta_{3}\left[R O A_{i j t-1}\right]\right)
$$

To test our second and third hypotheses, we use in the first step univariate analyses to control the potential differences in discretionary accruals and absolute value of discretionary accruals between firms audited by Big 4 and Non-Big 4 audit firms, and the effect of institutional investor monitoring on the managers opportunism. Then we use multivariate analyses. According to Becker et al. (1998), the model is as follows:

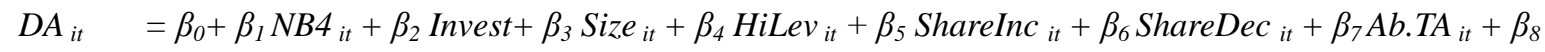

$$
\begin{aligned}
& O C F_{i t}+\text { New Auditor }_{i t}+\zeta
\end{aligned}
$$


Where

DA $_{\text {it }}=$ Estimated discretionary accruals;

NB4 ${ }_{\text {it }} \quad$ = Dummy variable equal to one if the two auditors are non-Big Four; 0

otherwise;

Invest $_{\text {it }} \quad=$ The percentage of the major institutional shareholders;

ShareInc it $_{\text {it }} \quad=$ Dummy variable equal to one when there is a decline of more than $10 \%$ of the total outstanding shares during the year; 0 otherwise;

ShareDec $_{\text {it }}=$ Dummy variable equal to one when there is a decline of more than $10 \%$ of the total outstanding shares during the year; 0 otherwise;

HiLev $_{\text {it }}=$ Dummy variable indicating whether firms are among the highest decile of leverage, by year and industry; 0 otherwise;

Size $_{\text {it }} \quad$ = Natural logarithm of total assets;

Ab. $\mathbf{T A}$ it

$=$ Absolute value of total accruals;

$\mathrm{OCF}_{\text {it }}$

$=$ Operating cash flows divided to total assets;

New Auditor ${ }_{\text {it }}$

$=$ Dummy variable equal to one when there is an auditor change; 0 otherwise;

\section{Control Variables}

Focusing on previous research we use variables related to the firm characteristics in our first model. According to the study of Broy and Weill (2008), we use long term debt (LTD) to control the effect of credit establishment on the choice of auditor. The latest empirical studies found a positive relation between large audit firm and long term debt in the United States context (Francis and Willson 1988; Eichenscher and Shield 1989; DeFond 1992; Reed et al. 2000). In addition, we use assets structure (ASTR) to control auditor expertise. Besides we use three measures of agency problem. We use size (Size, log of total assets), size square because Lenox (2005) found a non-linear association between size and auditor choice, growth (GRW, Sales variation) and square roots of employers number. Wang, Q and al. (2008) showed that growth is not associated to Non-Big 4 firms in China. They find a significant relation between small auditors and firm size. Risk is another factor that can affect the choice of an auditor. We use two measures of risk. The first one concern operating risk (O RISK) and the second is total risk (T RISK) developed by Piot (2001). Palmarose (1988) showed that firms audited by the Big 4 had a lower risk of litigation. Furthermore, we use the age (AGE) of the corporation to control the effect of culture on auditor choice. Following Asbaught and Warfield (2003), we coded 1 when the firm is listed on more than one financial market (MOM), 0 otherwise. Finally, we use return on assets (ROA) as an additional indicator of corporation risk.

According to previous research (Koh, 2007; Jeong and Rho, 2004; Becker et al, 1998), we include control variables in our second model. We use absolute value of total accruals because firms with large absolute value of total accruals will show higher discretionary accruals (Jeong and Rho, 2004). We also include shareInc and shareDec variable to control the manipulated earning due to the incentives associated to the selling of manager shareholding (Beneish, 1997). We use leverage ratio variable to control the effect of leverage on discretionary accruals. Furthermore, to control the political effect on discretionary accruals, we use Size (natural logarithm of total assets) and OCF (operating cash flows divided to total assets). Dechow et al. (1995) showed that operating cash flows are negatively correlated with level of accruals. Finally, to control the effect of switching auditor on discretionary accruals, we use a dummy variable; take 1 if the auditor changed, 0 otherwise.

\section{Results}

\subsection{Descriptive Statistics and Univariate Analyses}

Table 2 reports the descriptive statistics of our sample. In the French context, we note the lack of investor protection compared to common law countries. This conclusion depends on the ownership structure and investor characteristics. In the Big4 subsample, the mean detention of major institutional investor is $24.5 \%$ of the total share. The nationality of the institutional shareholders is generally coming from common Law countries and exactly US, UK and Canadian investors. Focusing on descriptive statistics summarizes (Table 3), the decrease of the institutional ownership is equal to 1\% in the case of Big 4 subsample after Enron Scandal. Contrary to this result, the mean of the institutional investor of the Non-Big 4 subsample is increased with $3 \%$ after Enron failure (from $26 \%$ to $29.4 \%$ ). This descriptive statistics show that the behaviour of the institutional investor was changed to large audit firm services after Enron collapse. 
Table 2. Descriptive statistics

\begin{tabular}{ccccccccccc}
\hline Variables & \multicolumn{4}{c}{ Corporation audited by Big 4 } & \multicolumn{4}{c}{ Corporation audited by Non-Big 4 } \\
\cline { 2 - 30 } & Mean & s.d & Min & Median & Max & Mean & s.d & Min & Median & Max \\
\hline Invest & 0.245 & 0.220 & 0 & 0.183 & 0.999 & 0.277 & 0.239 & 0 & 0.186 & 0.950 \\
LTD & 0.269 & 1.756 & 0 & 0.150 & 1.756 & 0.497 & 2.030 & 0 & 0.146 & 22.255 \\
ASTR & 0.177 & 0.158 & 0.0001 & 0.123 & 0.768 & 0.148 & 0.139 & 0.001 & 0.114 & 0.114 \\
AGE & 49.705 & 51.609 & 0 & 34 & 341 & 53.819 & 60.176 & 0 & 32 & 337 \\
SIZE & 14.120 & 2.137 & 8.755 & 80.059 & 658.942 & 13.634 & 2.076 & 8.634 & 13.315 & 18.186 \\
ORG & 135.266 & 130.757 & 5.744 & 80.059 & 658.942 & 98.314 & 107.534 & 7.416 & 52.611 & 556.383 \\
GRW & 0.154 & 0.354 & -7.743 & 0.078 & 3.920 & 0.163 & 0.331 & -0.614 & 0.090 & 3.630 \\
T RISK & 0.328 & 0.421 & 0.003 & 0.187 & 2.959 & 0.297 & 0.385 & 0.001 & 0.168 & 2.002 \\
O RISK & 0.559 & 2.967 & 0.000 & 0.022 & 34.665 & 0.084 & 0.273 & 0.000 & 0.023 & 2.352 \\
ROA & 0.033 & 0.316 & -5.701 & 0.032 & 3.238 & 0.0841 & 0.564 & -4.572 & 0.036 & 3.463 \\
DAC & -0.041 & 0.104 & -0.421 & -0.044 & 0.886 & -0.030 & 0.133 & -1.081 & -0.039 & 0.612 \\
Ab.TA & 0.067 & 0.076 & 0.000 & 0.048 & 0.881 & 0.077 & 0.110 & 0.000 & 0.051 & 0.967 \\
OCF & 0.129 & 1.089 & -15.887 & 0.073 & 20.486 & 0.248 & 0.959 & -1.126 & 0.074 & 10.090 \\
\hline
\end{tabular}

Table 3. Summarize descriptive statistics

\begin{tabular}{|c|c|c|c|c|c|c|c|c|}
\hline \multirow[t]{3}{*}{ Variables } & \multicolumn{4}{|c|}{ Before Enron scandal } & \multicolumn{4}{|c|}{ After Enron scandal } \\
\hline & \multicolumn{2}{|c|}{ Big 4} & \multicolumn{2}{|c|}{ Non-Big 4} & \multicolumn{2}{|c|}{ Big 4} & \multicolumn{2}{|c|}{ Non-Big 4} \\
\hline & Mean & Median & Mean & Median & Mean & Median & Mean & Median \\
\hline Invest & 0.252 & 0.22 & 0.260 & 0.151 & 0.241 & 0.160 & 0.294 & 0.245 \\
\hline LTD & 0.340 & 0.143 & 0.583 & 0.139 & 0.224 & 0.159 & 0.406 & 0.153 \\
\hline ASTR & 0.181 & 0.132 & 0.158 & 0.122 & 0.174 & 0.118 & 0.137 & 0.105 \\
\hline AGE & 44.861 & 32 & 55.743 & 32 & 52.778 & 36 & 51.766 & 31.5 \\
\hline SIZE & 13.874 & 13.601 & 13.694 & 13.300 & 14.277 & 13.967 & 13.571 & 13.327 \\
\hline ORG & 124.722 & 73.194 & 105.715 & 53.613 & 141.952 & 84.843 & 94.420 & 51.593 \\
\hline GRW & 0.219 & 0.123 & 0.212 & 0.147 & 0.113 & 0.055 & 0.111 & 0.060 \\
\hline T RISK & 0.322 & 0.225 & 0.302 & 0.199 & 0.332 & 0.153 & 0.291 & 0.144 \\
\hline O RISK & 0.901 & 0.024 & 0.091 & 0.022 & 0.341 & 0.021 & 0.077 & 0.028 \\
\hline $\mathrm{ROA}$ & 0.008 & 0.028 & 0.041 & 0.034 & 0.050 & 0.035 & 0.129 & 0.041 \\
\hline DAC & -0.050 & -0.052 & -0.044 & -0.043 & -0.035 & -0.040 & -0.016 & -0.035 \\
\hline Ab.TA & 0.076 & 0.056 & 0.080 & 0.054 & 0.060 & 0.044 & 0.073 & 0.049 \\
\hline OCF & 0.040 & 0.061 & 0.291 & 0.073 & 0.185 & 0.076 & 0.204 & 0.075 \\
\hline
\end{tabular}

Descriptive statistics reports also that Non-Big 4 clients are more leveraged than the corporations audited by large audit firms. 17\% of the total assets of the Big 4 clients are composed from fixed assets. This means that Big 4 have the ability expertise to audit the assets of international firms (Piot, 2001). After 2002, we note that the asset structure decrease in the case of the two subsample. This result confirms that the most of French corporation invest in intangible assets.

The descriptive statistics demonstrate that the size of Big 4 clients is more important than the Non-Big 4 clients before and after Enron collapse. The mean of total assets of the Big 4 clients is more than 1.3 million euro. The employ numbers signals those agency problems are very significant in the case of the French listed companies. This situation affects negatively the firm performance. According to this hypothesis, all last researchers confirm that the choice of the Big 4 auditors reduce the agency problems. The descriptive statistics reports that $31 \%$ of the Big 4 clients are listed on more one financial market.

Contrary to U.S context, the two groups of auditor's report negatively the discretionary accruals in French context. Before Enron failure, univariate analyses (Table 4) demonstrate that there are no significant differences of the audit quality in the mean and in the median through the discretionary accruals. The distribution of discretionary accruals before Enron scandal confirms this hypothesis.

After Enron collapse, univariate analyses documents that there is a difference of audit quality between the large and small audit through the discretionary accruals only on the mean $(t=1.885)$ at $10 \%$. This means that Big 4 came more conservative in the choice of the accounting methods. The absolute value of total accruals is an additional factor of managerial discretion. The parametric tests demonstrate that there is a difference after Enron failure through the absolute value of total accruals between the Big 4 and Non-Big 4 clients. This means that Big 4 does not accord to the manager more flexibility in accounting choices compared to small audit firms. Univariate analyses do not support our hypothesis. After Enron scandal, we note that 9\% of the Big 4 clients change their auditors. This result confirms that the reputation of the Big 4 audit firms decreased after the Enron failure. 
Table 4. Univariate analyses

\begin{tabular}{|c|c|c|c|}
\hline Variables & $\begin{array}{l}\text { Section A } \\
\text { Big } 4\end{array}$ & $\begin{array}{c}\text { Section B } \\
\text { Non-Big } 4\end{array}$ & $\begin{array}{c}\text { Section C } \\
\text { Difference Test } \\
(\mathrm{B} \neq \mathrm{A})\end{array}$ \\
\hline Before Enron & Median & Median & $\begin{array}{cl}\text { Mean } & \text { Median } \\
(t \text {-stat }) & (p \text {-value }) \\
\end{array}$ \\
\hline \multirow[t]{3}{*}{$\mathrm{DAC}$} & $\begin{array}{l}-0.050 \\
-0.052\end{array}$ & -0.044 & 0.006 \\
\hline & \multirow[t]{2}{*}{-0.052} & \multirow[t]{2}{*}{-0.043} & 0.009 \\
\hline & & & $(0.630)$ \\
\hline \multirow[t]{3}{*}{ Abso DAC } & \multirow{2}{*}{$\begin{array}{l}0.083 \\
0.056\end{array}$} & 0.081 & -0.002 \\
\hline & & \multirow[t]{2}{*}{0.054} & -0.002 \\
\hline & 0.056 & & $(-0.285) \quad(0.726)$ \\
\hline After Enron & Median & Median & $\begin{array}{l}\text { Median } \\
(p \text {-value })\end{array}$ \\
\hline \multirow[t]{3}{*}{ DAC } & -0.035 & -0.016 & 0.019 \\
\hline & \multirow[t]{2}{*}{-0.040} & \multirow[t]{2}{*}{-0.035} & -0.060 \\
\hline & & & $(1.733) \quad(0.149)$ \\
\hline \multirow[t]{3}{*}{ Abso DAC } & \multirow{3}{*}{$\begin{array}{l}0.077 \\
0.058\end{array}$} & \multirow{3}{*}{$\begin{array}{l}0.095 \\
0.053\end{array}$} & \multirow{2}{*}{$\begin{array}{c}0.017 \\
-0.005\end{array}$} \\
\hline & & & \\
\hline & & & $(1.885) \quad(0.829)$ \\
\hline
\end{tabular}

Khotari and al. (2005)

$\mathrm{TA} / \mathrm{A}_{\mathrm{ij} \mathrm{t}-1}=\alpha_{0}\left(1 / \mathrm{A}_{i j t-1}\right)+\beta_{1}\left(\Delta R E V_{i t}-\Delta R E C_{i t}\right) / \mathrm{A}_{i j t-1}+\beta_{2} P P E_{i t} / \mathrm{A}_{i j t-1}+\beta_{3} R O A_{t-1}+\xi_{t}$

Where

TA: Total accrual= Difference between earning and Operating cash flow

$\triangle \mathrm{REV}$ : change in net revenues for firm $\mathrm{i}$ in industry $\mathrm{j}$ for year $\mathrm{t}$;

$\triangle \mathrm{REC}$ : change in accounts receivable for firm $\mathrm{i}$ in industry $\mathrm{j}$ for year $\mathrm{t}$;

PPE: gross property plant and equipment for sample firm $\mathrm{i}$ in industry $\mathrm{j}$ for year $\mathrm{t}$.

ROA: Return on Assets;

$\xi_{\mathrm{t}}:$ random error term.

In section $\mathrm{A}$ and $\mathrm{B}, \mathrm{p}$-values for the means are from t-test and p-values for median are from signed rank test. In section $\mathrm{C}$, p-values for means are from t-test and p-values for medians are from Wilcoxon two-sample tests.

\subsection{Multivariate Analyses}

Table 5. Institutional shareholders and Auditor choice

\begin{tabular}{|c|c|c|c|c|}
\hline \multirow[t]{2}{*}{ Variables } & \multicolumn{2}{|c|}{ Before Enron failure } & \multicolumn{2}{|c|}{ After Enron failure } \\
\hline & Coefficient & t-student & Coefficient & t-student \\
\hline Intercept & 0.808 & 1.27 & 0.595 & 0.93 \\
\hline Invest & 0.016 & 0.16 & $-0.162 * *$ & -2.06 \\
\hline LTD & -0.011 & -1.48 & $-0.101 * *$ & -2.44 \\
\hline Asset & $0.301 *$ & 1.79 & $0.321 * *$ & 2.45 \\
\hline Age & $-0.001 * *$ & -2.67 & -0.005 & -1.44 \\
\hline Size & 0.082 & 0.58 & $0.336^{* *}$ & 2.77 \\
\hline $\mathrm{Size}^{2}$ & -0.003 & -0.71 & $-0.012 * *$ & -2.81 \\
\hline ORG & 0.004 & 1.22 & $0.008 * *$ & 3.05 \\
\hline GRW & 0.012 & 0.21 & 0.069 & 1.10 \\
\hline T RISK & -0.081 & -1.08 & -0.019 & -0.38 \\
\hline O RISK & $0.175 * *$ & 2.73 & $0.219 * *$ & 2.20 \\
\hline MOM & $0.184 * * *$ & 3.24 & $0.117 * *$ & 2.80 \\
\hline ROA & -0.010 & -0.20 & 0.013 & 0.12 \\
\hline Number of observation & \multicolumn{2}{|c|}{420} & \multicolumn{2}{|c|}{560} \\
\hline R squared & \multicolumn{2}{|c|}{$7.40 \%$} & \multicolumn{2}{|c|}{$8.57 \%$} \\
\hline $\operatorname{LR}(12)$ & \multicolumn{2}{|c|}{41.33} & \multicolumn{2}{|c|}{55.77} \\
\hline Prob & \multicolumn{2}{|c|}{0.000} & \multicolumn{2}{|c|}{0.000} \\
\hline
\end{tabular}

Big 4: Dummy variable, which equals 1 if the auditor is one of the Big Four, 0 otherwise; INST: Major institutional ownership percentage LRD: Long term debt to total assets; ASTR: Gross Property Plant and Equipment to total assets; $A G E$ : Corporation age since the foundation date; SIZE: Natural logarithm of total assets; $S I Z E^{2}$ : Square of size; $O R G$ : Square roots of total employers numbers; GRW: (Total sales of next year divided by total sales of current year) -1; T RISK: Total risk (see Appendix 1); O RISK: Operating Risk (see Appendix 1); MOM: Dummy variable, which equals 1 if the firm is listed on more than one market, 0 otherwise; 
ROA: Return on Assets.

$*, * *$ and $* * *$ denote significance at $\mathrm{p}<0.10,0.05$ and 0.01 respectively.

Table 5 reports the probit regression of the auditor choice model and the institutional investor ownership before and after Enron collapse. Empirical results demonstrate a positive and insignificant relation between Big 4 appointment and institutional shareholders before Enron failure $(p>0.1)$. After Enron failure, we find a negative and significant relation between institutional investor ownership and Big 4 choice at the level of 5\%. This empirical finding demonstrate the lack of the trust in Big 4 audit services, this is due to the role of Arthur Andersen LLP. Otherwise, the role of Arthur Andersen LLP in Enron failure can explain this result. The increase with $1 \%$ of the institutional shareholders decrease the probability of appointment one of the Big 4 audit firms with $16 \%$ in French context which characterized by the lack of investor protection according to LaPorta et al (1998). We note that the French context is characterized by the existence of the local large audit firm, but they are note one of the Big 4 networks. This characteristic of audit market in France influences the appointment of international large audit firms. The empirical finding associate to the institutional shareholders supports our first hypothesis and demonstrate the negative behaviour vis-à vis Big 4 choice after Enron collapse in France.

To test the relation between bank financing and Big4 choice, we use the leverage ratio. Before Enron scandal, we find a negative and insignificant relation between these two variables. This result is obtained by Piot (2001) in the case of firm's Investment Opportunity Set (IOS). After Enron scandal, we find a negative and in insignificantly relation between the Big 4 choice and long term debt at 5\%. This result demonstrates the increase of the lack of trust in the financial statement certified by international audit firms $(\mathrm{p}<0.05)$. To control the auditor expertise, we use the asset structure. The estimation result demonstrates a positive and significant relation between the assets structure and the Big 4 choice at the level of 5\%. This empirical finding demonstrates that Big 4 audit firms have the industrial expertise to audit the assets of their clients through the world. Recent empirical studies used market share industry indicator and they find that Big 4 have more industry expertise than the others auditors. Freguson et al. (2003) find that industry leader in Australia is audited by large audit firms. The size confirms this result. This variable is positively and significantly associated to the choice of the Big4 audit firm at the 5\%. To control the extension of agency problem, we use the age variable. We find inverse relation between the age of the corporation and the choice of large audit firms. After Enron scandal, this relation is not significant because the young firms does not choice one of the Big 4 auditors because the damage of their reputation. Furthermore, the operating risk is associated to the appointment of Big 4 before and after Enron scandal at the level of 5\%. This means that the corporations that have the high operating risk demonstrating their financial statement credibility throughout the Big 4 certification. But, the total risk is negatively and insignificant associate to the Big 4 appointment before Enron and after Enron scandal.

We adopt in the second part the multivariate analyses (OLS Regression) to test our second and third hypothesis, because the univariate analyses ignore control variables that can affect the managerial discretion through the discretionary accruals. Discretionary accruals are the dependent variable obtained from Khotari et al. (2005) model. To mitigate the effect of cross-sectional in the regression, we use the variability in the annual estimates (Bernard, 1987; Becker et al.1998; Jeong and Rho, 2004). 
Table 6. Multivariate Analyses: Audit quality differences and institutional monitoring

\begin{tabular}{|c|c|c|c|c|}
\hline \multirow[b]{2}{*}{ Variables } & \multicolumn{2}{|c|}{ Before Enron } & \multicolumn{2}{|c|}{ After Enron } \\
\hline & $\begin{array}{l}\text { Pooled Estimate } \\
\qquad(t \text {-stat })\end{array}$ & $\begin{array}{c}\text { Mean of three year } \\
\text { estimation } 2000-2002 \\
\text { a } \\
(t \text {-stat })\end{array}$ & $\begin{array}{l}\text { Pooled Estimate } \\
\text { ( } t \text {-stat) }\end{array}$ & $\begin{array}{c}\text { Mean of four year } \\
\text { estimation } \\
2003-2006^{\mathrm{a}} \\
(t \text {-stat })\end{array}$ \\
\hline Intercept & $\begin{array}{l}0,032 \\
(0,92)\end{array}$ & $\begin{array}{c}0,032 \\
(0,518)\end{array}$ & $\begin{array}{l}0.050 \\
(1.24)\end{array}$ & $\begin{array}{c}0,048 \\
(0,453)\end{array}$ \\
\hline N-Big 4 & $\begin{array}{l}-0,006 \\
(-0,62) \\
\end{array}$ & $\begin{array}{c}-0,005 \\
(-0,326) \\
\end{array}$ & $\begin{array}{l}0.021 * \\
(1.81)\end{array}$ & $\begin{array}{r}0,024^{*} \\
(1,756) \\
\end{array}$ \\
\hline Invest & $\begin{array}{l}0,020 \\
(0,93)\end{array}$ & $\begin{array}{c}0,021 \\
(0,586) \\
\end{array}$ & $\begin{array}{l}-0.001 \\
(-0.05)\end{array}$ & $\begin{array}{c}-0,001 \\
(-0,034) \\
\end{array}$ \\
\hline Size & $\begin{array}{l}-0,005 \\
(-2.09) \\
\end{array}$ & $\begin{array}{c}-0,005 \\
(-1,104) \\
\end{array}$ & $\begin{array}{l}-0.002 \\
(-1.02) \\
\end{array}$ & $\begin{array}{c}-0,002 \\
(-0,396) \\
\end{array}$ \\
\hline HiLev & $\begin{array}{l}0,006 \\
(0.36)\end{array}$ & $\begin{array}{c}0,005 \\
(0,179) \\
\end{array}$ & $\begin{array}{l}0.017 \\
(1.00)\end{array}$ & $\begin{array}{c}0,011 \\
(0,177)\end{array}$ \\
\hline Share Inc & $\begin{array}{l}0,027 \\
(1.87) \\
\end{array}$ & $\begin{array}{c}0,022 \\
(0,855) \\
\end{array}$ & $\begin{array}{l}-0.009 \\
(-0.52) \\
\end{array}$ & $\begin{array}{l}-0,011 \\
(0,020)\end{array}$ \\
\hline Share Dec & $\begin{array}{l}0,003 \\
(0,24) \\
\end{array}$ & $\begin{array}{c}0,002 \\
(0,104) \\
\end{array}$ & $\begin{array}{l}-0.006 \\
(-0.54) \\
\end{array}$ & $\begin{array}{c}-0,005 \\
(-0,281) \\
\end{array}$ \\
\hline Ab.TA & $\begin{array}{l}-0,201 \\
(-3,86)\end{array}$ & $\begin{array}{c}-0,263 \\
(-2,857)\end{array}$ & $\begin{array}{c}-0.323 * * * \\
(-5.02)\end{array}$ & $\begin{array}{c}-0,205^{* * * *} \\
(-1,715)\end{array}$ \\
\hline OCF & $\begin{array}{l}-0,006 \\
(-1,32) \\
\end{array}$ & $\begin{array}{c}-0,004 \\
(-0,419) \\
\end{array}$ & $\begin{array}{l}-0.002 \\
(-0.44)\end{array}$ & $\begin{array}{c}-0,001 \\
(-0,331) \\
\end{array}$ \\
\hline New Auditor & $\begin{array}{l}0,001 \\
(0,05)\end{array}$ & $\begin{array}{c}0,005 \\
(0,144)\end{array}$ & $\begin{array}{l}-0.015 \\
(-0.77)\end{array}$ & $\begin{array}{c}-0,030 \\
(-0,799)\end{array}$ \\
\hline Adj.R squared & $2.92 \%$ & & $3.91 \%$ & \\
\hline
\end{tabular}

Average of Adj.R

squared $10.58 \%$

$11.44 \%$

$\mathrm{DA}_{\mathrm{it}}=$ Estimated discretionary accruals;NB4 ${ }_{\mathrm{it}}=$ Dummy variable equal to one if the two auditors are non-Big Four; 0 otherwise; Invest ${ }_{i t}=$ The percentage of the major institutional shareholders; ShareInc ${ }_{\text {it }}=$ Dummy variable equal to one when there is a decline of more than $10 \%$ of the total outstanding shares during the year; ShareDec ${ }_{\text {it }}=$ Dummy variable equal to one when there is a decline of more than $10 \%$ the total

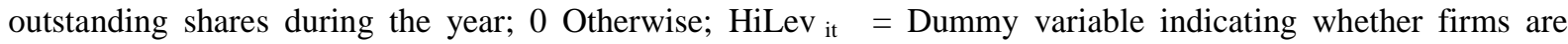
among the highest decile of leverage, by year and industry; 0 otherwise; Size $_{i t}=$ Natural logarithm of total assets; $\mathrm{Ab} . \mathrm{TA}_{\mathrm{it}} \quad=$ Absolute value of total accruals; $\mathrm{OCF}_{\text {it }}=$ Operating cash flows divided to total assets; New Auditor $_{\text {it }}=$ Dummy variable equal to one when there is an auditor change; 0 otherwise;

a The coefficient are the mean of the all year estimation. The t-statistics are calculated using the variability in the yearly coefficient estimate as in Bernard (1987).

$*, * *$ and $* * *$ denote significance at $\mathrm{p}<0.10,0.05$ and 0.01 respectively.

Table 6 reports the result of our estimation. The coefficient of Non-Big 4 audit firms is negative and insignificant before Enron collapse. This result proves that there is no differentiation of the magnitude of discretionary accruals in French context before Enron collapse. This means that the clients of Non-Big 4 and Big 4 report the same level of discretionary accruals in French context post Enron scandal. After Enron scandal, the coefficient of the Non-Big 4 dummy variable indicates that Non-Big 4 clients report the discretionary accruals $2.1 \%$ higher than the Big 4 clients after Enron scandal. This result supports our univariate analyses. Big 4 coming more conservatism in the accounting choices and they do not accord the flexibility choice to the manager. The first preoccupation of Big 4 auditors is to restore their good reputation through the reliability of the financial statements of their clients. More than one factor explains that Big 4 are more conservative than Non-Big 4. For example, Big 4 has the financial and the human resources that can affect the skill and the practice of their employers.

Contrary to the Non-Big 4 coefficient, the institutional shareholders coefficient is negative and insignificant associated to the discretionary accruals after Enron scandal. This empirical result demonstrates that the institutional shareholders monitoring activity does not influence significantly the manager opportunism after Enron collapse. But this group of investor confide this mission to the other corporate governance mechanism like the audit committee.

Size variable is negatively and insignificant before and after Enron scandal. The negative coefficient on leverage dummy variable is not the same result obtained by DeAngelo et al. (1994), Becker et al. (1999) and Jeong and 
Rho (2004). This empirical finds does not shows the relation between leverage and financial distress in French context. It means that troubled companies are not more likely to reduce earning management due to contractual negotiation. Besides, the coefficient of the absolute value of the total accruals is negative. This means that the manager of the firms with large accruals did not tend to reduce earning management. Furthermore, we find a negative and insignificant coefficient of the number of total share increasing related to the discretionary accruals. This empirical conclusion explains the control of the French Market Authority on manager private information disclosure after Enron scandal via Law Security Act.

Share decreasing dummy variable is insignificant before and after Enron scandal. We also note a negative and insignificant coefficient on the operating cash flow. Dechow et al. 1994, Becker et al. (1995), Jeong and Rho (2004), Chen et al. 2005 showed that discretionary accruals are negatively correlated with cash flow. The switch auditor variable is negatively and insignificant associated to the discretionary accruals after Enron scandal. This result is different from the result obtained by Becker et al. (1999) in United States context and Jeong and Rho in South Korea between 1994 and 1998.

\section{Conclusion}

The aim of this paper is to study the relation between the institutional shareholders, auditor choice and earning management after Enron collapse in French context which characterized by the weak of investor protection compared to Common Law Countries. Empirical finding demonstrate that the ownership of the major institutional shareholders affect negatively the choice of one of the international large audit firm after Enron scandal. This result demonstrates the lack of institutional investor confidence in Big 4 services. This is due to the Arthur Andersen LLP, one of the Big 5 in the world, in Enron failure. The increase with $1 \%$ of the major institutional shareholders decreases the Big 4 designation with $16 \%$. We note also, that French audit market is characterized by the existence of major local auditor and they are note on of the international audit firms. This characteristic affected the Big 4 appointment in France and especially after Enron collapse.

Furthermore, we find that some control variables can affect positively the choice of large audit firms in France. Long term debt is one of these variables that can affect negatively the appointment of Big 4 after Enron collapse. This means that the credit establishment does not used only annual financial statements to accord a credit amount to their clients, but they use other factor that can guarantee the pay the credit. Contrary to credit establishment, the companies listed on more one market choose the large audit firms because they search to signal their financial statement credibility to their potential and actual financial users.

To justify their reputation and to keep their brand name, Big 4 influences the adoption of accounting methods and they do not accord the flexibility to the manager in the choice of accounting practice. Univariate and multivariate analyses demonstrate that Big 4 clients have a less level of discretionary accruals compared Non-Big 4 clients after Enron failure. Otherwise, the Non-Big 4 clients report the discretionary accruals with $2 \%$ higher than Big 4 clients after 2002. Contrary to our prediction, we find the negative and insignificant relation between major institutional investor and discretionary accruals. This means that institutional investor can confide the monitoring activity to other corporate mechanisms and especially the audit committee. The audit committee is one of the most important corporate governance mechanisms that can affect the adoption of the accounting methods and affect the discretionary accruals level. But this depends on the characteristics of the audit committee.

\section{References}

Abbott L. J., Parker, S., Peters, G. F., \& Raghunandan, K. (2003). The association between audit committee characteristics and audit fees. Auditing: A J Practice \& Theory, 22(2), 17-32. http://dx.doi.org/10.2308/aud.2003.22.2.17

Ashbaugh, H., \& Warfield, T. D. (2003). Audits as a Corporate Governance Mechanism: Evidence from the German Market. Journal of International Accounting Research, 2 1-21. http://dx.doi.org/10.2308/jiar.2003.2.1.1

Asthama, S. C., Balsam, S., \& Krishnan, J. (2003). Audit firm reputation and client stock price reactions: Evidence from the Enron experience. Working paper, Temple University. http://dx.doi.org/10.2139/ssrn.320327

Azibi, J., Amri, H., Azibi, H., \& Tondeur, H. (2016). Legal Aspect of the Audit Profession from the Antiquity to the Financial Security. The International Journal of Business and Management, 12(4), 161-164.

Becker, C., Defond, M., Jiambalvo, J., \& Subramanyam, K. R. (1998). The effect of audit quality on earnings management. Contemporary accounting research, 15, 1-24. 
http://dx.doi.org/10.1111/j.1911-3846.1998.tb00547.x

Beneish, M., \& E. Press. (1995). The Resolution of Technical Default. The Accounting Review, 70, 337-353.

Bernard, V. L. (1987). Cross-sectional dependence and problems in inference in market-based accounting research. Journal of Accounting Research, 25, 1-48. http://dx.doi.org/10.2307/2491257

Broy, G., \& Weill, L. (2008). Does Leverage Influence Auditor Choice? A Cross-Country Analyses. Applied Financial Economics, 18, 1-17. http://dx.doi.org/10.1080/09603100701222325

Bulter, M., Andew, J. L., \& Willenborg, M. (2004). An Empirical Analyses of Auditor Reporting and its Association With Abnormal Accruals. Journal of Accounting and Economics, 3, 139-165. http://dx.doi.org/10.2139/ssrn.298700

Cahan, S., \& Zhang, W. (2006). After Enron: Auditor Conservatism and Ex-Andersen Clients. The Accounting Review, 81, 49-82. http://dx.doi.org/10.2308/accr.2006.81.1.49

Callen, J. L., \& Morel, M. (2002). The Enron-Andersen Debacle: Do equity markets react to auditor reputation? SSRN Working paper. http://dx.doi.org/10.2139/ssrn.341440

Carcello, J. V., Hermanson, D. R., Neal, T. L., \& Riley, R. A. (2002). Board characteristics and audit fees. Contemporary Accounting Research, 19, 365-384. http://dx.doi.org/10.1506/CHWK-GMQ0-MLKE-K03V

Chaney, P., \& Phlipich, K. (2002). Shredded Reputation: The Cost of Audit Failure. Journal of Accounting Research, 40, 1221-1245. http://dx.doi.org/10.1111/1475-679X.00087

Chen, C., Lin, C., \& Lin, Y. (2004). Audit partner tenure, audit firm tenure, and discretionary accruals: does longer auditor tenure impair earnings quality? Contemporary Accounting Research, 25, 415. http://dx.doi.org/10.1506/car.25.2.5

DeAngelo, L. (1981). Auditor Size and Audit Quality. Journal of Accounting and Economics, 1983-1999. http://dx.doi.org/10.1016/0165-4101(81)90002-1

Dechow, P., Solan, R., \& Sweeney, A. (1995). Detecting Earning Management. The Accounting Review, 70, 193-225.

DeFond, M. (1992). The Association between Changes in Client Firm Agency Costs and Auditor Switching. Auditing: A Journal of Practice and Theory, 11, 16-31.

DeFond, M. L., \& Jiambalvo, J. (1993). Debt Covenant Violation and Manipulation of Accruals. Journal of Accounting and Economics, 17, 145-176. http://dx.doi.org/10.1016/0165-4101(94)90008-6

DeFond, M. L., \& Park, C. W. (1997). Somoothing Income in Anticipation of Future Earnings. Journal of Accounting and Economics, 23, 115-140. https://doi.org/10.1016/S0165-4101(97)00004-9

Directive of European Parliament. (2006).

Dye, R. (1993). Auditing standards, legal liability, and auditor wealth. Journal of Political Economy, 101, 887-914. http://dx.doi.org/10.1086/261908

Eisenberg, T., \& Macey, J. R. (2003). Was Arthur Andersen Different? An empirical Examination of Major Accounting Firms' Audit of Large clients. Journal of Empirical Legal Studies, 1, 263-300. https://doi.org/10.1111/j.1740-1461.2004.00008.x

Ferguson, A., Francis, J., \& Stokes, D. (2003). The effects of firm-wide and office-level industry expertise on audit pricing. The Accounting Review, 78, 429-448. http://dx.doi.org/10.2308/accr.2003.78.2.429

Francis, J., \& Wilson, E. (1988). Auditor Changes: A Joint Test of Theories Relating to Agency Costs and Auditor Differentiation. The Accounting Review, 64, 663-682.

Francis, J. R., Maydew, M. L., \& Sparks, H. C. (1999). The role of Big 6 auditors in the credible reporting of accruals. Auditing: A Journal of Practice and Theory, 18, 17-34. http://dx.doi.org/10.2308/aud.1999.18.2.17

Gadhoum, Y. (2000). Family Control and Grouping Family: Possible Expropriation via Dividends. Working Papers, CENTOR papers.

Gillan, S. L., \& Starks, L. (2000). Corporate Governance Proposals and Shareholders Activism: The Role of Institutional Investors. Journal of Financial Economics, 57, 275-305.

http://dx.doi.org/10.1016/S0304-405X(00)00058-1 
Guedhami, O., \& Pittman, J. (2006). Ownership Concentration in Privatized Firms: The Role of Disclosure Standards, Auditor Choice, and Auditing Infrastructure. Journal of Accounting Research, 44, 889-929. http://dx.doi.org/10.1111/j.1475-679X.2006.00219.x

Jeong, S.W., \& Rho, J. (2004). Big Six Auditors and Audit Quality: The Korean Evidence. The International Journal of Accounting, 39,175-196. http://dx.doi.org/10.1016/j.intacc.2004.02.001

Jones, J. (1991). Earnings management during import relief investigations. Journal of Accounting Research, 29, 193-228. http://dx.doi.org/10.2307/2491047

Kane, G. D., \& Velury, U. (2004). The role of institutional ownership in the market for auditing services: An empirical investigation. Journal of Business Research, 57, 976-983. http://dx.doi.org/10.1016/S0148-2963(02)00499-X

Koh, P. S. (2007). Institutional Investor Type, Earnings Management and Benchmark Beaters. Journal of Accounting and Public Policy, 26, 267-299. http://dx.doi.org/10.1016/j.jaccpubpol.2006.10.001

Kothari, S. P., Leone, A. J., \& Wasley, C. E (2005). Performance Matched Discretionary Accruals measures. Journal of Accounting and Economics, 39, 163-197. http://dx.doi.org/10.1016/j.jacceco.2004.11.002

Krishnamurthy, S., Zhou, J., \& Zhou, N. (2002). Auditor reputation, Auditor Independence and The Stock Market Reaction to Andersen's Clients. SSRN Working paper. http://dx.doi.org/10.2139/ssrn.348960

La Porta, R. F., Lopez-de-Silvanes, A., Shleifer, A., \& Vishny, R. W. (1998). Law and finance. Journal of Political Economy, 106, 1113-1155. http://dx.doi.org/10.1086/250042

Lakhal, F. (2006). Les Mécanismes de Gouvernement d'Entreprise et la Publication Volontaire des Résultats en France. Comptabilité -Contrôle -Audit, 12, 69-92. https://doi.org/10.3917/cca.122.0069

Lennox, C. (2005). Management ownership and audit firm size. Contemporary Accounting Research, 22, 205-227. http://dx.doi.org/10.1506/K2CG-U6V0-NPTC-EQBK

Lin, Z. J., \& Liu, M. (2009). The Impact of Corporate Governance on the Auditor Choice: Evidence From China. Journal of International Accounting, Auditing and Taxation, 18, 44-59. http://dx.doi.org/10.1016/j.intaccaudtax.2008.12.005

Maug, E. (1998). Large shareholders as monitors: is there a trade-of between liquidity and control? Journal of Finance, 53, 65-98. http://dx.doi.org/10.1111/0022-1082.35053

McConnell, J. J. H., \& Servaes, H. (1990). Additional evidence on equity ownership and corporate value. Journal of Financial Economics, 27, 595-612. http://dx.doi.org/10.1016/0304-405X(90)90069-C

Nelson, K. K., Price, R. A., \& Rountree, B. R. (2008). The market reaction to Arthur Andersen's role in the Enron scandal: Loss of reputation or confounding effects? Journal of Accounting and Economics, 46(2), 279-293. http://dx.doi.org/10.1016/j.jacceco.2008.09.001

Palmrose, Z. V. (1988). An analysis of auditor litigation and audit service quality. The Accounting Review, 55, 55-73.

Piot, C. (2001). Agency costs and audit quality: Evidence from France. The European Accounting Review, 10, 461-499. http://dx.doi.org/10.1080/713764630

Piot, C. (2003). Coûts d'agence et Changements des Commissaires Aux Comptes: Une approche Empirique. Comptabilité -Contrôle -Audit, 2, 5-30. https://doi.org/10.3917/cca.092.0005

Reed, B. J., Trombley, M. A., \& Dhaliwal, D. S. (2000). Demand for Audit Quality: The case of Laventhol and Horwath's auditees. Journal of Accounting, Auditing and Finance, 2, 183-198.

Schleifer, A., \& Vishny, R. (1997). A survey of corporate governance. Journal of Finance, 52, 737-783. http://dx.doi.org/10.1111/j.1540-6261.1997.tb04820.x

Simunic, D., \& Stein, M. (1987). Product differentiation in auditing: auditor choice in the market for unseasoned new issues. The Canadian Certified General Accountants' Research Foundation.

Smith, M. P. (1996). Shareholders Activism by Institutional Investor: Evidence From CaalPERS. The Journal of Finance, 51, 227-252. http://dx.doi.org/10.1111/j.1540-6261.1996.tb05208.x

Subramanyam, K. R. (1996). The Pricing of Discretionary Accruals. Journal of Accounting Economics, 22, 249-282. http://dx.doi.org/10.1016/S0165-4101(96)00434-X

Wall Street Journal. (1995a). Nine CONCERNS NAMED by Big Pension Fund as underperformers. February 3 , 
$\mathrm{C} 2$.

Wall Street Journal. (1996a). Law-legal beat: CALpers wins a lead role in suit over Grace's severance packages. September 12, C12.

Wall Street Journal. (1997). CALpers targets Apple, Reebok, others in its latest list of worst performers. February 11, C5.

Wang, Q., Wong, T. J., \& Lijun, X. (2008). State Ownership, The Institutional Environment, and Auditor Choice: Evidence From China. Journal of Accounting and Economics, 46, 112-134.

https://doi.org/10.1016/j.jacceco.2008.04.001

Watts, R., \& Zimmerman, J. L. (1986). Positive Accounting Theory Prentice Hall. Englewood Cliffs (NJ).

\section{APPENDIX A: RISK COMPUTATION USING WORLDSCOPE DATABASE}

\section{Operating Risk}

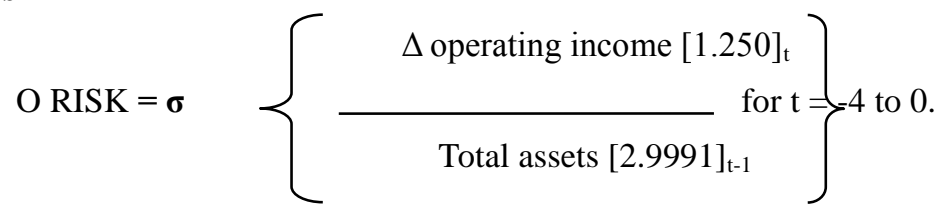

$$
\operatorname{TRISK}=\sigma\left\{\begin{array}{c}
\Delta(\text { Common share outstanding [5.001] } * \text { Price closing [5.301] })_{\mathrm{t}}+ \\
\frac{\text { interest expense on debt }[1.251]_{\mathrm{t}}+\text { cash dividend paid }[4.551]_{\mathrm{t}}}{[\text { Total Assets [2.999] }- \text { Common Equity [3.501] }+ \text { Closing Price [5.301] }} * \\
\text { Common share outstanding [5.001] }]_{\mathrm{t}-1}
\end{array}\right\}
$$

$$
\mathrm{t}=-4 \text { to } 0 \text {. }
$$

Note: [Worldscope items between brackets]

\begin{tabular}{|c|c|c|c|c|c|c|c|c|c|c|c|c|}
\hline & Big4 & Invest & Ltd & Asset & Age & Size & ORG & GRW & TRisk & ORisk & MOM & ROA \\
\hline Big 4 & 1.000 & & & & & & & & & & & \\
\hline Invest & -0.064 & 1.000 & & & & & & & & & & \\
\hline Ltd & -0.057 & -0.062 & 1.000 & & & & & & & & & \\
\hline Assets & 0.087 & 0.071 & 0.082 & 1.000 & & & & & & & & \\
\hline Age & -0.035 & 0.059 & 0.075 & 0.286 & 1.000 & & & & & & & \\
\hline Size & 0.106 & 0.065 & -0.076 & 0.319 & 0.380 & 1.000 & & & & & & \\
\hline ORG & 0.137 & -0.062 & 0.064 & 0.303 & 0.406 & 0.760 & 1.000 & & & & & \\
\hline GRW & -0.012 & -0.106 & -0.031 & -0.126 & -0.151 & -0.173 & -0.138 & 1.000 & & & & \\
\hline TRisk & 0.035 & -0.070 & 0.031 & -0.053 & -0.048 & -0.200 & -0.036 & 0.075 & 1.000 & & & \\
\hline ORisk & 0.089 & -0.026 & 0.011 & 0.017 & 0.142 & 0.051 & 0.126 & 0.020 & 0.321 & 1.000 & & \\
\hline MOM & -0.038 & -0.020 & -0.050 & 0.031 & -0.061 & -0.013 & -0.065 & -0.012 & 0.016 & 0.061 & 1.000 & \\
\hline ROA & -0.056 & 0.006 & 0.298 & 0.049 & 0.108 & -0.026 & 0.038 & -0.070 & -0.103 & -0.051 & -0.020 & 1.000 \\
\hline
\end{tabular}

\section{Correlation matrices: Institutional shareholders and Auditor choice}

Big 4: Dummy variable, which equals 1 if the auditor is one of the Big Four, 0 otherwise; INST: Major institutional ownership percentage $\boldsymbol{L R D}$ : Long term debt to total assets; $\boldsymbol{A S T R}$ : Gross Property Plant and Equipment to total assets; $\boldsymbol{A G E}$ : Corporation age since the foundation date; SIZE: Natural logarithm of total assets; $\boldsymbol{S I Z E}^{2}$ : Square o size; $\boldsymbol{O R G}$ : Square roots of total employers numbers; $\boldsymbol{G R \boldsymbol { W }}$ : (Total sales of next year divided by total sales of current year) -1; T RISK: Total risk (see Appendix 1); $\boldsymbol{O}$ RISK: Operating Risk (see Appendix 1); MOM: Dummy variable, which equals 1 if the firm is listed on more than one market, 0 otherwise; ROA: Return on Assets.

Note: We find a high correlation between ORG and Size variables; we adopt the Variance Inflation Factor method $(V I F)$. We find that the multicoliniarity between this two variables does not affect the regression result (VIF=1.73). 
Correlation matrices: Audit quality differences and institutional monitoring

\begin{tabular}{|c|c|c|c|c|c|c|c|c|c|c|}
\hline & DAC & Big4 & Invest & Size & HiLev & Share Inc & Share Dec & Ab.TA & $\mathrm{OCF}$ & New Auditor \\
\hline$\overline{\mathrm{DAC}}$ & 1.000 & & & & & & & & & \\
\hline Big 4 & -0.043 & 1.000 & & & & & & & & \\
\hline Invest & 0.012 & -0.064 & 1.000 & & & & & & & \\
\hline Size & -0.016 & 0.106 & 0.065 & 1.000 & & & & & & \\
\hline HiLev & 0.007 & 0.025 & -0.121 & 0.408 & 1.000 & & & & & \\
\hline Share Inc & 0.005 & -0.024 & -0.038 & -0.004 & 0.050 & 1.000 & & & & \\
\hline Share Dec & -0.019 & -0.057 & 0.023 & 0.029 & -0.016 & -0.313 & 1.000 & & & \\
\hline Ab.TA & -0.190 & -0.053 & -0.024 & -0.213 & -0.040 & 0.086 & -0.044 & 1.000 & & \\
\hline $\mathrm{OCF}$ & -0.032 & -0.053 & 0.031 & -0.092 & 0.098 & -0.040 & 0.072 & 0.016 & 1.000 & \\
\hline New Auditor & -0.034 & 0.068 & -0.027 & 0.049 & 0.027 & -0.009 & 0.037 & 0.020 & 0.015 & 1.000 \\
\hline
\end{tabular}

$\mathbf{D A}_{\text {it }}=$ Estimated discretionary accruals; NB4 ${ }_{\text {it }}=$ Dummy variable equal to one if the two auditors are non-Big Four; 0 otherwise; Invest $_{\text {it }}=$ The percentage of the major institutional shareholders; ShareInc ${ }_{\text {it }}=$ Dummy variable equal to one when there is a decline of more than $10 \%$ of the total outstanding shares during the year; ShareDec it $^{=}$Dummy variable equal to one when there is a decline of more than $10 \%$ the total

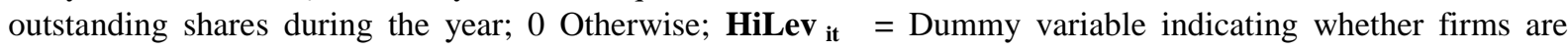
among the highest decile of leverage, by year and industry; 0 otherwise; $\mathbf{S i z e}_{\mathbf{i t}}=$ Natural logarithm of total assets; $\mathbf{A b} . \mathbf{T A} \mathbf{A}_{\text {it }} \quad=$ Absolute value of total accruals; $\mathbf{O C F} \mathbf{F}_{\text {it }}=$ Operating cash flows divided to total assets; New Auditor $_{\text {it }}=$ Dummy variable equal to one when there is an auditor change; 0 otherwise;

\section{Copyrights}

Copyright for this article is retained by the author(s), with first publication rights granted to the journal.

This is an open-access article distributed under the terms and conditions of the Creative Commons Attribution license (http://creativecommons.org/licenses/by/4.0/). 